\title{
Literature and Security: CIA Engagement in the Arts. What Philosophers of Education Need to Know and Why
}

LIAM GEARON

Corresponding Author

E-mail address: liam.gearon@education.ox.ac.uk

Correspondence: Liam Gearon, University of Oxford, 15 Norham Gardens, Oxford OX2

$6 \mathrm{PY}$.

Email: liam.gearon@education.ox.ac.uk

MARION WYNNE-DAVIES

Marion Wynne-Davies, School of Literature and Languages, University of Surrey, Guildford, Surrey GU2 7XH.

Email:M.Wynne-Davies@surrey.ac.uk

\section{Abstract}

These are broad and expansive themes and so what we wish to do is to provide a perhaps dramatic case study example of state engagement with the arts for political and security purposes. Our critical case is that of the Central Intelligence Agency (CIA) engagement with the arts during the Cold War and newly uncovered archival evidence of the $\mathrm{CIA}$ involvement with the writers' organisation which is still thriving today, International PEN. Our argument is that the state security engagement with the arts and literature is an important exemplar of what we term the influence of public education by often covert means, which may derogatively be referred to as propaganda, or what Jameson called the 'political unconscious'. From the archival evidence arising from CIA engagement with the arts we derive three principles of intellectual framing for analysis of the critical aesthetic of philosophy of education: (1) the political aesthetic of security and literature; (2) cultural citizenship as security; (3) the educational ecosystem of literature as securitisation. In sum, we suggest philosophers of education sharpen their treatments of literature in education with more realistic and informed assessments of the aesthetic in political and security contexts. Methodologically, by implication, we think we also make the case for philosophers of education to make greater and more frequent use of primary documentation, particularly archival sources in order to be able to substantiate such sharpened treatments.

\section{INTRODUCTION}

The relationship between literature and security may at first glance seem a distant one. And the connection perhaps even further removed from philosophy of education. We present evidence here that may convince otherwise. In broad theoretical terms we present the case for contextualising the literature and security interface as an extension of the ancient relationship between philosophy, literature and politics. The idea of a contested relationship between authors and autocrats, writers and their dictators is thus as old as Plato's oft-cited hypothetical expulsion of the poets from the Republic, or the ancient quarrel, still characterising debates around language and philosophy emergent from the Enlightenment and variants of its reactive Romantic aftermath (Williams, 2016). It is an abiding relationship between literature and politics that endures wherever writers are 
repressed or indeed act themselves as agents of religious, moral or ideological repression

(Alexander, 2005; Karolides et al., 2011; Orwell, 1946).

If as Hobsbawm (2007) rightly tells us, all modern revolutions can be traced back to the French Revolution, an originating link between literature and politics can be traced to Rousseau. In an early prize-winning essay-a discourse on the respective merits of the arts and the sciences-submitted to the Academy of Dijon, the young Rousseau, much in the way Stalin would, castigates artists for a lack of concern with attention to matters pursuant of social justice (Rousseau, 1997a, 1997b. Martha Nussbaum (2012) might today disagree. In her influential and much cited Not for Profit: Why Democracy Needs the Humanities, she takes the contrary view, arguing that it is the arts, humanities and literature which sustain and enrich not detract from democracy.

We show, however, a hidden hand within that sustaining of democracy through the arts. The security and intelligence apparatus we articulate here is, we argue, a modern-day element, a contemporary manifestation or facet (if a neglected one) of an educational ecosystem of cultural construction, the operationalising means of political engineering of the cultural. Stalin understood this in making his diktat to the Union of Soviet Writers, declaring artists should be 'engineers of the human soul'. It is an extension of the argument presented by Trotsky (1971) in Literature and Revolution. Reich Minister of Propaganda in Nazi Germany Joseph Goebbels understood it too and realised that the Nazi book-burnings of 1933 were the preface to other fires.

Liberal democracies have not, however, been averse to their own cultural engineering either. The empirical, archival and theoretical framing of our literature review and discussion show that such cultural engineering has involved security and intelligence agencies like the CIA. Many philosophers of education may find this surprising. They may even find it initially irrelevant.

The dictum that 'the pen is mightier than the sword' is thereby inverted. The pen is a weapon, and has long served this purpose. As histories of censorship and freedom of expression attest, the writer has long served as a symbol of political oppression in two-fold ways, as the recipient of aestheticpolitical repression or, where certain literary or artistic views support authoritarian regimes they can be the agents themselves of aesthetic-political power. Here PEN (Poets, Essayists, Novelists), which draws its raison d'etre from this organisation's dictum, is all the more appropriate a demonstration of the proximity of literature and security through its engagement with the CIA.

Our findings are empirical and methodologically dependent upon the use of a US literary archive, the Ransom Center, at the University of Texas at Austin. Both authors have spent a considerable number of years undertaking archival research on the Special Collections of the International PEN holding. Our conclusions are theoretical and provide a threefold intellectual framing for analysis of the critical aesthetic of philosophy of education: (1) the political aesthetic of security and literature; (2) cultural citizenship as security; (3) the educational ecosystem of literature as securitisation.

\section{CIA ENGAGEMENT IN THE ARTS: THE CASE OF INTERNATIONAL PEN (POETS, ESSAYISTS, NOVELISTS)}

PEN is a writers' organisation founded in 1921. In the aftermath of World War I its founding President was John Galsworthy, author of the Forsyte Saga, and just prior to his death, winner of the Nobel Prize for Literature, one of a number of PEN Presidents to do so. From its inception PEN consistently rejected political affiliation and propaganda, a commitment reiterated in two key 
international congresses. During the Brussels Congress of June 1927 the Federated PEN Clubs declared their adhesion to the following principles:

Literature, national though it be in origin, knows no frontiers, and should remain common currency between nations in spite of political or international upheavals.

In all circumstances then and particularly in time of war, works of art, the patrimony of humanity at large, should be left untouched by national or political passion.

Members of the PEN Clubs will at all times use what influence they have in favour of good understanding and mutual respect between the nations. (Harry Ransom Center, PEN Papers, Acquisition 1, Box 5; hereafter cited by Acquisition and Box numbers. All quotations courtesy of The Harry Ransom Center, The University of Texas at Austin.)

Subsequently, with the rise of Nazism and Fascism in Western Europe, and with Stalin's Soviet Empire well established in the East, at the 10th International Congress Budapest 25-27 May 1931, Galsworthy reminded delegates: 'I hope you will forgive me when I say that the time has come to speak of the due qualities in definite words about what our PEN Association does and does not stand for. The founding centre [London] - I know you will readily believe me-know exactly with what ideals the PEN Association was founded and to what ideals we must adhere furtherly if it is to continue to exist.' He outlines five principles:

1st: The PEN stands for literature in the sense of art, not of journalism, not of propaganda! And for the diffusion of literature as art from country to country.

2nd: The PEN stands for the hospitality and friendliness between writers in their own country and with writers of all other countries.

3rd: The PEN stands for the principle that its members shall do or write nothing to promote WAR.

4th: The PEN stands for humanly conduct.

5th: Such words, as nationalism, inter-nationalism, democracy, aristocracy, imperialistic, antiimperialistic, bourgeoisie, revolutionist or alike other words with political significance must not be used in connection with the PEN. The PEN has nothing to do with the state-or Party-politics and cannot be use for State- or Party-interests of any country (1.10)

The aim that literature should be 'untouched by national or political passion' and that 'propaganda' or 'words with political significance' should have no place in PEN has been sustained, with the organisation's current website retaining, almost verbatim, the original 1927 first principle, 'Literature knows no frontiers and must remain common currency among people in spite of political or international upheavals'.

Yet, over the last 25 years the CIA's investment in various artistic, academic and cultural circles and publications has been exposed with some intriguing parallels for PEN (Miller Harris, 2016; Stonor Saunders, 2013; Whitney, 2018). This article, therefore, turns the focus onto PEN and, in so doing, demonstrates the importance of archival research, for International PEN and its administration were deeply implicated in the CIA's cultural cold war. In particular, the investigation focusses upon Arthur 
Miller and David Carver-President and Secretary of International PEN, respectively-from 1964 to 1966.

\section{December 1964: David Carver and the Foreign Office}

Before 1965, the clandestine association between PEN and the security services in the US and the UK is uncertain. The first, still faint, evidence emerges in the memo recorded by Carver relating to meetings he had with the British Foreign Office at the end of 1964 (2.8). On 7 December 1964, Carver received a personal letter from Robin (Robert) Cecil-with the salutation 'Dear David' and the sign off 'Yours ever' - asking him to come to an informal meeting at the Cultural Department of the Foreign Office. In a memorandum following the meeting, which took place on 6 January 1965, Carver lists, with care, the points covered during his conversation with Cecil, Richard Speight and Sir Francis Head. Cecil, it seems, was interested in 'the cultural relations between Eastern Europe and this Country [the UK]' as well as in the upcoming 1965 International Bled Congress and how PEN and the Foreign Office 'could collaborate'. After some discussion it was decided that 'P.E.N. might, in fact, be regarded as sponsoring invitations to individuals [from East Europe] ... while the East Europe Committee and the British Council would foot the bill'. Interestingly, Carver notes, 'At this point I made mention of IWF but did not disclose sources of revenue'. The 'IWF' that Carver refers to was the International Writers' Fund whose 'source of revenue' was the $\mathrm{CIA}$, a fact Carver appears to have known and, simultaneously, wished to conceal. This is an intriguing point in itself, since it suggests that Carver was working to obtain funds for PEN from both the UK Foreign Office and the CIA. However, financing visits by Eastern European authors was not Cecil's only interest in calling the meeting; he was also keen to discuss 'the International Presidency ... possible American candidates [and] the French Centre'. The ensuing discussion of the next President of International PEN demonstrated a preference for an American candidate and referred to the possibility that the French PEN Centre might prove problematic since they were putting up their own candidate.

As such, this seemingly innocuous meeting between old friends focused upon the two key elements that were to establish International PEN policy for the next decade and align it closely with the UK's and USA's foreign policy, as well as the covert activities of MI6 and the CIA. Importantly, as far as Carver and Cecil were concerned there were two key PEN 'planks' that would serve to facilitate the West's battle against the East: funding and the presidency of International PEN. The first step was, therefore, to recruit an American PEN president who could be manipulated in the cultural cold war against Russia.

\section{An American for President: February 1965}

Accordingly, in February 1965 Carver went to New York in search of an American candidate for the international presidency. The history of PEN records that Arthur Miller, the renowned American playwright, was the final choice. However, while Carver was exploring the possibilities of a US president, he was also establishing links with Russia. Alain Whitman, the General Secretary of the PEN American Center wrote to Carver on 16 January 1965 asking him to attend 'this P.E.N. cocktail party for the Russian visitors with which, so fortunately for us, your own time of arrival here coincides', although Whitman acknowledges that the Russians are not PEN guests, rather that, 'our State Department has asked us to entertain them' (2.20). Less than a month after meeting Cecil, Carver was already investigating American candidates for the presidency and establishing links with Russian writers. 
The most interesting account of Carver's subsequent meeting with Arthur Miller, is Miller's own, recorded in his biography, Timebends (1987). The initial contact was made over the phone by Keith Botsford who was Secretary of the IWF (his name appears alongside Carver's on the notepaper) and who was also active in International PEN. Moreover, Christopher Bigsby in his biography of Miller notes that Botsford had 'served briefly in military intelligence' and had considerable knowledge of 'those employed, directly or indirectly, by the CIA' (Bigsby, 2011, p. 90). The next day Botsford arrived at Miller's apartment in Paris with David Carver and they started to persuade Miller to allow his name to be put forward for the next President of International PEN. At first Miller was reluctant and at this point he draws a perceptive portrait of Carver:

Carver snapped open his golden cigarette case. Certain as I was that I wanted nothing to do with this new diversion from writing, there was no way of cutting short this great figure of a Briton, blond of hair, blue of eye, with silky skin as white as the inside of a grapefruit rind, two jolly pink rosettes on his cheeks, and shoulders as broad as the back of a wagon (Miller, 1987, p. 566).

The impression is of a quintessentially upper-class Englishman, but Miller uses some disconcerting words and images. The social urbanity of the 'golden cigarette case' is undercut by the 'grapefruit rind', 'rosettes' and 'wagon'. Suddenly, Carver's poise seems like a veneer, concealing a much more mundane, working-class identity. Indeed, while Miller imagines the Englishman as both the horse with the rosettes and the wagon pulled by that horse, he never suggests that Carver was driving the wagon. Moreover, Miller's suspicion that Carver was being directed by others was remarkably accurate, as the American found himself wondering: 'whether our State Department or CIA or equivalent British hands might be stirring this particular stew' (Miller, 1987, p. 567).

Still, Carver continued to woo Miller by stressing PEN's credentials as 'depoliticized' and presenting the presidency as a way to 'speak to the sterility of the Cold War' and 'save lives' (Miller, 1987, p. 566). Miller, however, remained suspicious of Carver's and Botsford's true intentions, so, still wondering if the Englishmen was working alongside the CIA or MI6, the American decided to 'flush them out' by asking 'What if I wanted to invite Soviet writers to join PEN?' (Miller, 1987, p. 567). But Miller was taken aback by the response: 'Carver's mouth dropped open. "Why, that would be wonderful!"' (p. 567). Of course, Arthur Miller was working on the assumption that any organisation involved with Western governments would reject friendly overtures towards Russia and, consequently, if Carver welcomed links with the Soviets, then PEN must be a non-political and independent group. Carver's understanding of the conversation was very different. Indeed, he must have been delighted that both planks of the policy he had discussed with Cecil had fallen together so very neatly. Not only had he won over Miller, whose candidacy for the presidency was now assured, but Carver had also engineered Miller's innocent support, via PEN, for MI6's and the CIA's clandestine cultural cold war. Writing with hindsight in his biography, Miller notes that he managed, to wheedle out of the FBI in 1986, 'a 1965 cable to Washington from the US Embassy in Moscow describing my reception there, two short weeks before this visit of Carver's, as "semi-official" and "warm" (p. 568)

The political implications were considerable: the CIA, assisted by MI6, now had in International PEN, a complicit Secretary and assistant (Carver and Botsford) and an unwittingly compliant President (Miller). The next stage was to implement a new strategy for wooing writers in Russia and the Eastern Bloc and the set for such activity was to be the 33rd International PEN congress in Bled. 
Before moving on to discuss that Congress, however, it is important to point out that Carver was not a Machiavellian character abusing PEN for his covert political masters, nor was Miller an innocent American abroad. Miller's suspicions had already been aroused, as noted in his autobiography. On Carver's part, while he failed to comment in print himself, there is one telling point in his discussion with Miller: that PEN was on the verge of going 'out of business' (Miller, 1987, p. 566). When pushed by Miller, Carver explained that they need more members of note, but this response was somewhat disingenuous because at the beginning of 1966 going 'out of business' was a very real possibility for International PEN as they had very little cash and no reserves. For Carver it must have been an invidious position, since PEN was able to 'save lives', as he had claimed to Miller, but only if he, Carver, secretly did the bidding of the CIA in exchange for the cash that funded PEN'sactivism.

\section{Bled Congress, 1965}

Carver wrote to Miller on 2 June 1965 to let him know what to expect at the Bled Congress, although, as he notes, Keith Botsford and Lewis Galantiere, had already discussed logistics with Miller (2.13). Carver goes on to explain that the French have not withdrawn their candidate, Miguel Angel Asturias, but that Miller has overwhelming support and that the election will be 'a formality'. Although the French Centre campaigned fiercely for Asturias, they claimed to have nothing against Miller, but saw the American as Carver's candidate and in a pamphlet entitled 'To Know French' they warned against the consolidation of Carver's power (2.13). Carver, meanwhile, having sorted out the issue of the presidency, turned his attention to the Russians. In the same letter to Miller, he explains that the idea of Soviet observers will be introduced at Bled. He notes that he has already had talks in Paris with Alexey Alexandrovich Surkov and Konstantin Simenov and that four 'distinguished Soviet writers have been asked to attend the Congress: Anna Akmatova, Aleksandr Tvardovsky, Konstantin Fedin and Mikhail Sholokhov. Of these, it is worth noting that both Surkov and Simenov were, respectively, head and secretary of the Soviet Union of Writers and were Party-men, never questioning the hard censorship of their fellow Russian writers. The 'distinguished ... writers' were more mixed. Fedin, as chair of the Soviet Union of Writers, and Sholokhov were both respected and committed Soviet citizens. Akmatova and Tvardovsky were, by the 1960s, respected, but had in the past been accused of dissidence. Akmatova was a Russian poet acclaimed in both East and West; she was also 76 at the time of the Bled conference. Tvardovsky was the editor the literary journal, Novy Mir which had published, in 1962, the controversial novel One Day in the Life of Ivan Denisovitch by Alekandr Solzhenitsyn. The composition of the group Carver writes about is, therefore, mixed, with a predominance of loyal Soviets, but with two possibly dissident voices aimed at reassuring Miller that PEN could indeed act as a liberalising force within Russia. Carver ended by briefing Miller about his forthcoming trip to Moscow. Notably, Carver did not inform Miller that the visit would be paid for by the Ford Foundation (as Galantiere confirms in a letter to Carver on 21 May 1965 (2.20 and 24)), which was of course one of the CIA's front-organisations used to channel funds.

While Carver had Miller and the French Centre in hand, Keith Botsford had run into difficulties with regards to Bled, since the two men, Matje Bor and Joze Javorsek, charged with organising the congress were at loggerheads. Botsford was despatched to Budapest to discuss the arrangements for the congress and reported the difficulties to Carver on 26 October 1964 (2.13). Botsford described Bor as a man 'not without political ambitions' and pointed out that Javorsek, in sharp contrast, opposes the socialist Yugoslav government. Botsford went on to explain the reason for Javorsek's political views: 
No sooner had he arrived [from France in 1948] he was arrested, thrown into jail and tortured. His wife died in childbirth while he was in prison, and it was not until two years had elapsed that he was permitted out of solitary confinement ... [leaving him] somewhat soured on socialist society (2.13).

The whole affair exploded during the two men's meeting with Botsford: Bor attacked Javorsek, who promptly resigned. Subsequently, Botsford asked Carver 'to give Javorsek the help he needs' and, although there are no extant letters showing what 'help' Carver provided, the organisation of the Congress resumed and Botsford was soon free to turn to the next stage of wooing the Russian and Eastern Bloc authors. But, how to do this?

The most significant innovation at the Bled Congress was the introduction of Round Table discussions (Tables Rondes) that, as Botsford noted in a summary report, would 'make the annual International Congress of PEN more interesting, varied and intellectually stimulating' (2.24). Although, at first, this appears to be a laudable intellectual endeavour, the first aim in the report suggests a more political intention. Botsford writes:

The opportunity offered by the fact that the Congress was sponsored by a centre in East Europe, where the PEN is particularly active [is]...to advance the East-West dialogue (2.24).

In effect, the invitations to the Round Tables were able to offset the 'official writers', who were invited by the East European Centres, against writers invited solely by the International Secretariat (such as Carver), and these Round Table writers, as Botsford notes, were 'almost totally members of the "liberal" movements within their own countries'. In particular, the innovation proved successful with regard to Russia, as Botsford again comments: 'The presence of the Soviet writers in the Tables Rondes, treated as individuals and not as delegates, may be counted one of the triumphs of the Bled Tables Rondes'. However, not all delegates were convinced. The Round Tables were criticised for bringing in non-PEN members, the invites being organised by the International Secretary rather than the host centre and the fact that those PEN members who attended were allowed in only as 'observers'. This was, of course, precisely the point, since Carver's CIA-driven strategy was to use PEN as a vehicle for stirring up protest against Soviet control both in Russia and the Eastern Bloc countries.

Evidence for this infiltration of PEN may be found in the funding patterns. Significantly, Botsford's report lists those organisations that offered financial aid to the non-official writers: 'UNESCO ... the Ford Foundation, the Farfield Foundation and the International Writers' Fund' (2.24). While there is no evidence to suggest that UNESCO was funded by the $\mathrm{CIA}$, there is ample proof that the agency used both the Ford Foundation and the Farfield Foundation as vehicles in the cultural wars against the Soviet Union during the 1960s (Stonor Saunders, 2013). Moreover, Carver admitted in a letter to Storm James in 1967 that the International Writers' Fund was similarly bankrolled by the ClA (Birkett, 2009, p. 330). Finally, in a letter written a year later to George Minden, whose own association with the CIA will be discussed in the next section, Carver indicated that further substantial funding had been obtained from the Free Europe Committee, yet another front for the distribution of CIA monies (2.24). Indeed, UNESCO funded only one Round Table as part of its own three-year project, 'New Means of Creation', while the CIA indirectly provided the money for all the other Round Tables at Bled with their predominantly Eastern Bloc 'liberal' writers. 
After the Congress, Susan Sontag wrote a perceptive report commenting on the Round Tables and their political aspect:

PEN has always had the reputation of being 'outside politics' which accounts for its strength and survival in Eastern Europe. Yet there is no doubt the function, purpose, raison d'être of PENwhether it's admitted or not-is a political one: to liberalize the writer's situation (2.24).

She goes on to comment specifically on the Round Tables and the attendance of 'seven Russian observers'; she notes that Anna Akhmatova, Andrey Voznesensky and Aleksandr Solzhenitzyn were all invited, but did not attend. Instead 'we got Surkov himself ... and only one writer of some note, the novelist Leonid Leonov'. The promise of some dissident Russian writers was, therefore, not fulfilled and they were substituted by Surkov whose Soviet sympathies have already been outlined and Leonov who had been made Deputy of the Supreme Soviet of the Soviet Union in 1950. While Botsford's report claims success at developing possibly subversive links with Russian and Eastern Bloc writers, Sontag's more honest-and unwitting-report reveals that the Soviets were far from unaware of the CIA's attempts at infiltration and countered the West's creation of open Round Tables by sending delegates who would report faithfully back to their own government agencies. Through all this, it seems that Miller remained unaware of the situation since in his speech on accepting the presidency he claimed that the PEN Congress at Bled and PEN as an organisation offered,

an opportunity for men of different nations and conflicting ideologies, to face one another in a way which no other area provides (2.21).

At the close of the Bled Congress, PEN was, therefore, at the cusp of change, with a number of factors-all political-competing for its identity and raison d'être. Carver, striving to sustain the organisation with funding from the $\mathrm{CIA}$, continued to pursue the cultural cold war tactics demanded by his paymasters thereby ensuring that international PEN events were open to possible dissident writers from Russia and the Eastern Bloc countries. Surkov, in turn, worked with the Soviet authorities to counter such moves by packing out any Round Tables with stalwart Soviet supporters. Miller appears, at first, to be a dupe in such political machinations, but he used his speeches and personal contacts to suggest that individual writers could rise above national politics. And Botsford? Well, for Botsford, either the Bled Congress proved too much or, perhaps more likely, he had failed in his endeavour to lure Soviet dissidents, since, as Bigsby notes, 'Botsford, Carver had decided, was "too much of a liability", and wrong for PEN' (Bigsby, 2011, p. 106). Moreover, Carver needed to move on to the next Congress, this time in New York.

\section{CIA Funding and Preparations for the New York Congress: Winter/Spring 1965-66}

The most significant challenge for Carver as he set out to plan the New York Congress was where to find the money, but with his new $\mathrm{ClA}$ backing, he proved to be very effective at raising funds. By the end of 1965 Carver had already lined up US\$ 5,700 to pay for the travel and subsistence of 'East Europeans'. As he informed Lewis Galantière (President of PEN American Center) in a letter dated 18 December 1965, 'the Ford Trustees have come through with the money' (2.20). Carver noted that he dealt with 'Minden' who was prepared to fund the East European writers but who also sought to control who Carver intended to ask: 'he also gave me a list of his choices'. In a revealing aside, Carver 
confides: 'Between you and me, I must persuade Minden to give me a certain amount of latitude over choice' (2.20).

Carver's careful phrasing - the secrecy of the problem, the fact that he has to 'persuade' Minden, and that he only expects a 'certain amount' of choice' - evidences the complex nature of the International Secretary's dealings with the CIA. For George Minden was behind the Free Europe campaign to provide free books to Eastern Bloc countries, an organisation and strategy that was funded by the CIA (Reisch, 2013) while the Ford Foundation has long since been recognised as a known conduit for $\mathrm{CIA}$ funding. Here, Minden is the most important figure in terms of linking funding to specific East European authors.

Minden clearly courted Carver for, by January 1966 Carver was on George Minden's Christmas card list. But Carver was not a passive player in the cultural cold war games and, on the 11 January 1966, he sent a specific list of Eastern European writers that he hoped Minden would fund to travel to the New York Congress and indicates that, 'The International Writers' Fund is opening an account in New York and the monies could be paid into that account', thereby successfully concealing the source of the funds (2.20). At four times remove- $\mathrm{ClA}$, Minden/Free Europe, International Writers Fund, PEN-Carver clearly felt that he had covered his tracks. The whole rigmarole was to unravel only one year later, but it held for the New York Congress, allowing Carver to continue the plan espoused in the meeting with Cecil in 1965 to influence Eastern writers. In this light, the 'short report on the Bled Congress' that Carver encloses with the letter is significant.

Carver immediately notes that Bled was 'notable for the many writers of distinction from both East and West who met together in a series of Round Table Discussions' (2.24). Indeed, he points out the 'outstanding success' of these meetings providing, as they did, an 'intimate exchange of views between writers of East and West'. However, he goes on to express worries that they will be unable to match in New York the funding provided for Bled by the Free Europe Committee. And this is where John C. Hunt comes into play. Hunt was the CEO of The Congress for Cultural Freedom (CCF) in Paris, yet another front for CIA funding. Hunt was in close correspondence with Carver about a number of seemingly unrelated issues; for example, in May 1966, Hunt and Carver were working together to assist Marion Bieber in her new role at the CCF (2.20). However, Beiber was another element of the CIA's infiltration into PEN since she was assigned to Carver by Hunt as an assistant in the organisation of the New York Congress. Tellingly, Carver wrote to Hunt on 22 February 1966 saying that 'it would probably be more tactful if she were attached to my staff [rather than that of the New York PEN Center]' (2.20). Cementing such links, on 9 February 1966 Hunt wrote to Carver expressing pleasure that 'the Ford people' have made 'a substantial grant to the American PEN' in order to ensure the success of the Congress (2.20). In effect, therefore, Carver's campaign to secure CIA funding for the PEN New York Congress was supremely successful; financial support from the CIA was provided through a range of front-facing agencies, including the Ford Foundation, the Free Europe Committee and the Congress for Cultural Freedom, in addition to the direct support from Beiber, who had been seconded to help PEN administration. Yet, neither the CIA nor Carver had forgotten the way Surkov had hijacked their attempts to woo Eastern Bloc writers at the Bled Congress by packing out the delegations with Soviet sympathisers. So, rather than appeasement, they chose, for New York, a direct challenge-the case of Andrei Sinyavsky. 
Sinyavsky was a protégé of Boris Pasternak who published short satiric stories criticising life under the Soviet regime. These were published in the west under the pen name Abram Tertz and his work is generally regarded as one of the key elements in the demise of the Soviet Union (Coleman, 1997). However, in 1965 Sinyavsky was arrested, along with his friend Yuli Danbiel, and was sentenced to seven years imprisonment on the charge of writing anti-Soviet propaganda. Sinyavsky was released in 1971 and allowed to emigrate to France where he took up a post as professor at The Sorbonne University. But in Spring 1966, when the strategies for the New York Congress were underway, Sinyavsky's predicament seemed to offer the ideal opportunity to challenge Russian orthodoxy and to send a message of hope to other dissident writers in both Russia and the Eastern Bloc.

As such, a letter dated 22 Feb 1966 from the British Arts Council to Carver, shows that the Arts Council and PEN were devising a way to publish 'an edition of Sinyavsky's book' (2.20). In this letter Carver reports to Minden that he has had a meeting about Sinyavsky with Leo Labetz, whose journal, Survey, was funded by The Congress for Cultural Freedom and, therefore, by the CIA. In addition, the meeting involved Manya Harari, who had already worked as the translator, even if indirectly, with the CIA on its campaign to promote Boris Pasternak's Doctor Zhivago. Indeed, she went on to translate Sinyavsky's Unguarded Thoughts. This strategy was followed up by Carver in April 1966 when he visited Moscow with the aim of persuading the Union of Soviet Writers to 'put forward a plea for clemency for Sinyevsky and Daniel', an issue that, Carver argued, was tied closely to the attendance of Russian observers at the forthcoming New York congress. The response was blunt: Surkov told Carver that 'he would have no mercy for Sinyavsky and Daniel; they were cowards' (3.3).

\section{New York Congress, 1966}

The 1966 PEN Congress was held in New York under the title 'The Writer as Independent Spirit' and, for Miller in particular, should be regarded as a significant success. At the same time, Carver's political interventions, even with the financial support of the CIA, failed to secure the intended 'intimate exchange of views between writers of East and West' that had characterised his achievement at Bled. Or, perhaps, these exchanges were somewhat too revealing. The final days of the congress witnessed stormy scenes that were reported by Robert Temple in a dispatch to the Louisville Courier Journal (available http://www.robert-temple.com/nostalgia/pen.html). Temple describes the 'near-explosion' that occurred when Valery Tarsis, whose autobiographical novel, Ward 7 (1965) had exposed Russia's use of psychiatric hospitals to incarcerate dissidents, condemned the 'Communist government' and demanded 'a hot war' against Russia. Significantly, Tarsis referred specifically to the meeting between Carver and the Union of Soviet Writers in Moscow, pointing out that the Russians 'fully approved the infamous sentence passed by the Soviet kangaroo court on Sinyavsky and Daniel'. Indeed, The New York Times reported that the very Russian delegates Carver had hoped to woo to New York, withdrew at the last moment from attending the Congress because they feared 'embarrassing debates ... over the imprisonment of' Sinyavsky and Daniel' (2.10).

It was not until five months later that Miller finally commented upon the West/East problems that had occurred at the New York Congress, thereby tacitly addressing Carver's interventions and defending PEN's non-political agenda. Miller's argument is, however, somewhat convoluted. He begins by acknowledging that Tarsis, in common with other exiled writers, has 'used his freedom to speak politically, but at the same time Miller asserts that PEN 'can still call ourselves non-political ... 
because I happen to believe that literature is a liberating fact for yourself-even under a dictatorship' (P.E.N. News, American Center, January 1967, XIII). In other words, while a writer can 'speak politically' in terms of their personal 'freedom', that does not mean that PEN is political, even though those writers spoke in a PEN congress. More telling, however, are Miller's beliefs, since he affirms that the act of writing is a 'liberating' force under a 'dictatorship'. Of course, Miller could well have been alluding to his own appearance before the House of Un-American Activities Committee in 1956, but he was also undoubtedly referring to Tarsis and the other dissident writers persecuted by the Soviet 'dictatorship' and by 1969 Miller had been banned from entering the Soviet Union because of his vigorous campaigning against such repression.

Finally, therefore, it is useful to revisit PEN's idealistic 1927 assertion that it should be an organisation 'untouched by national and political passion', because by the mid-1960s such lofty claims were being severely undermined. Indeed, the power of pragmatism may be evidenced by the speed with which Carver's assurances to Miller in the spring of 1965 that PEN was 'depoliticized' metamorphosed into Miller's own 'political passion' as he defended the freedom of political dissidents in Russia. Yet, there is another telling point made by Carver in his attempts to win over Miller: that, as International President and Secretary of PEN, they could 'save lives'. This aim carries equal, or perhaps more, moral weight than PEN's adherence to being 'depoliticized', yet saving lives costs money. And this is why archival research is so important because, while rumours had surfaced (9 May 1967 the New York Post and 2.27), the PEN papers at the Harry Ransom Center prove categorically that PEN was funded by the CIA.

\section{LITERATURE AND SECURITY: WHAT PHILOSOPHERS OF EDUCATION NEED TO KNOW AND WHY}

On the basis of this case study of English PEN, and a review of the wider scholarly and research literature, we argue that philosophers of education need to know about $\mathrm{CIA}$ and wider security and intelligence agency engagement in the arts for at least three reasons, all of which collectively amount to important aspects of philosophy of education's critical aesthetic.

\section{(1) The Political Aesthetic of Security and Literature}

First, to be meaningful, interrogations of the aesthetic cannot remain apolitical abstractions. In 'Why I Write', George Orwell (1946) identified 'four great motives for writing, at any rate for writing prose' - the egotistical, the aesthetic, the historical and the political. Using 'political' in 'the widest possible sense' by this he means to '[D]esire to push the world in a certain direction, to alter other people's idea of the kind of society that they should strive after' (Orwell, 1946). It is this latter purpose with which Orwell most closely identified, and it is this relationship between writing and politics, aesthetics and security, with which we are concerned here.

That all of the totalitarian movements of the 20th century saw literature and the arts useful in the shaping of political systems indicates the power of literature in modernity (Adamson, 2003). Indeed, progressive modern versions of freedom of expression are sterile without considering such harsh political realities (Alexander, 2005; Appignanesi, 2006). Thus, writing and the arts played an important political role in post-Revolutionary Russia. Trotsky's (1971 [1925]) Literature and Revolution here delineated the writers' role for the Soviets, dissolving pre-Revolutionary and capitalist models of individual self-expression to an emphasis upon the collective. The All-Russian Association of Proletarian Writers was part of this. It later formed the basis for the Union of Soviet 
Writers, formed by the Central Committee of the Communist Party on 23 April 1932. The first (1934) Congress of the Union of Soviet Writers demanded not only a particular literary style (Socialist Realism) but a political, that is revolutionary, purpose to literature, a role that may be seen clearly in their persecution of Sinyavsky and their challenge to PEN. The Congress's most infamous voice, however, was Andrei Zhdanov, who conveyed Stalin's chillingly mechanist vision for the Soviet aesthetic, that writers and artists were 'engineers of the human soul' (Garrard and Garrard, 1990).

The West too of course, often covertly, sought to engineer the arts and the political unconscious, and in so doing provide a positive image of liberal, democratic polity, as we have demonstrated in our case study. The wider political-security aesthetic is demonstrated in more sustained studies such as: Linda Risso's pioneering study, Propaganda and Intelligence in the Cold War (2014); Sarah Miller Harris's (2016) The CIA and the Congress for Cultural Freedom in the Early Cold War: The Limits of Making Common Cause; the contemporary classic, Frances Stonor Saunders' (2013) The Cultural Cold War: The CIA and the World of Arts and Letters; and, more recently, Joel Whitney's (2018) Finks: How the C.I.A. Tricked the World's Best Writers. Peter Finn and Petra Couvee (2015) in The Zhivago Affair detail the CIA involvement of Boris Pasternak's Dr Zhivago, in other words how a Nobel Laureate in literature was a cultural reflection of Cold War tensions. Lashmar and Oliver (1998) Britain's Secret Propaganda War: Foreign Office and the Cold War and Nicholas Wilkinson's (2009) Secrecy and the Media: The Official History of the United Kingdom's D-Notice System: The Official History of the D-notice System demonstrate the hidden hand of government security and intelligence agencies in the media over a significant number of decades. Philosophers of education should themselves examine not simply their own aesthetic and educational presuppositions, but the institutional and wider socio-political framing in which these are formed.

\section{(2) Cultural Citizenship as Security}

Two, we argue, an effort towards making explicit the political themes of the aesthetic, what Jameson called 'the political unconscious', is a manifest responsibility of educationalists in general and philosophers of education in particular. Such analysis follows in an established tradition of aesthetics and politics (Adorno et al., 2007); or Guy Debord's (1984) Society of the Spectacle, which decries the subversion of authentic experience in the ecstasy of consumption: 'All that once was directly lived has become mere representation' (Debord, 1984). Older echoes of the same are found in Walter Benjamin's (2008) The Work of Art in the Age of Mechanical Reproduction and resonances in Baudrillard's (2005) The System of Objects. As Fredric Jameson (2002) declares in The Political Unconscious the aesthetic narrative is a socially symbolic act which constructs social reality. JeanFrancois Lyotard's (1984) The Postmodern Condition: A Report on Knowledge details the end of the grand narrative through a process of fragmentation into minor and localised stories, a dialogue to which our case study contributes. This power of narrative and grand narrative is obvious in all political discussions of the aesthetic: there is here no clearer dichotomy for example than between Matthew Arnold's (2009) Culture and Anarchy (western culture as bastion against barbarism) and Edward Said's (1994) inverted Culture and Imperialism (western culture as purveyor of barbarism). In sum, the literary and political can be shown to be not only of aesthetic contention but a function of political contestation.

Our advancement of such theories of cultural construct and political consciousness is to make explicit the security and intelligence mechanism which underlie such cultural constructions. Or more 
particularly, to suggest that in the political sphere there is a security and intelligence mechanism which enables, facilitates and promotes cultural works, across all spheres, pictorial and visual as well as literary. As intimated, an enormous literature exists on contemporary thought on the political aesthetic, or the aesthetics of the political.

We may provide one example from Lyotard, a philosopher beloved and berated for preoccupations with narrative and grand narrative. The very terminology of this 'postmodern' thinker's central focus upon narrative as knowledge allows us to make a connection between art and the world it represents. Lyotard's philosophy of the arts, which is also a philosophy of events, is, like Plato, concerned with the power of representation. Lyotard was interested in the traditional affective power of representation, its subliminal impact, the unconscious of the sublime, as many artists and writers were also interested in the psychanalytic study of the figures, symbols, the displaced desires of the dream, the form and the force of imagination.

Lyotard conceptualises much of this aesthetic theory in The Differend (Sawyer, 2014), where in art as in politics, ultimate resolutions are rarely possible. Art like politics is a process of representation not a resolvable or reasoned finality. Indeed, for Lyotard part of the power, and the pleasure, of art, is that it is unreasonable. In the visual arts Lyotard took favour with French impressionists such as Paul Cezanne for subliminally, impressionistically, disrupting accepted (or traditional) views of the world and of modernity, subverting the realist painters that had dominated French and European art, to present alternative visions.

Lyotard also saw in the differend a means not only of aesthetic but also political disruption. It is why Lyotard focused so much on literary and pictorial experimentation, and in particular the avant-garde. Here, Lyotard saw the American art movement known as Abstract Expressionism as epitomising this power of aesthetic disruption through avant-garde experimentation, in life, literature, in art. Yet this latter exemplar from a much cited author in the philosophy of education, provides reasons why philosophers might need at times more than reasons. In which case perhaps a glance over the empirical, that is political, security and intelligence contexts of the arts might be useful when lauding high theory heroes and heroines. Lyotard and abstract expressionism is as good an illustrative starting point as any.

Several respectable academic sources have already been cited to highlight the still contentious, and contended, relationship between the CIA and the arts, but a simple online search using the words 'abstract expressionism and the CIA' reveals several hundred links, dating back decades and leading to the present, revealing the sudden rise to global prominence of Abstract Expression-Jackson Pollock arguably at its fore-and accounts replete with accusations of covert funding, the shadowy movements behind the art world of powerful forces. Much of this-like the connection of Nelson Rockefeller, President in the 1940s and 1950s of the New York Museum of Modern Art, to the newly created $\mathrm{ClA}$-is still contested. Yet one wonders if the challenges to the established order for which Lyotard so lauded abstract expressionism might have seemed quite so disruptive of the political order.

This too was the time of new power elites, and C. Wright Mills' (2000) The Power Elites remains a text of paramount importance from the period. The Power Elites identified the nexus of business, government and military-security networks as now ruling America. Its author, a maverick sociology professor, died somewhat prematurely at aged 45 . Thus an emergent and significant literature is 
preoccupied with researching new forms of the elite and the powerful in the social and political sciences-Williams' (2012) Researching Power, Elites and Leadership and Domhoff et al.'s (2017) Studying the Power Elite (Williams, 2012). None of this literature really penetrates into the operational side of the arts. Philosophers, and philosophers of education concerned with the arts in education, might venture to examine some of the empirical evidence about the power structures behind the arts, literary, visual, and so forth, as an element at least of their reflections on the power of aesthetics in education (see authors in this Special Issue).

$\mathrm{ClA}$ interest in the arts is thus here not merely an historical Cold War curiosity. On the publicly available website of the Central Intelligence Agency (CIA) there is a regular book review section called The Intelligence Officer's Bookshelf. Its purpose is twofold: first, to provide reviews of books which relate to matters of interest to the Intelligence Community (IC); second, to provide responses to the works written by non-IC authors on the Intelligence Community and to correct perceived faults and flaws in argument and evidence. Weiner's (2007) Legacy of Ashes, a history of the CIA, for example, comes in for some sharp correctives from the CIA reviewer (Dujmovic, 2007).

Further, philosophers themselves have been specific targets of security and intelligence interest. The CIA's Reports on Philosophers (Weinberg, 2017) details several formerly confidential Central Intelligence Agency reports on philosophy. One cited is on Soviet philosophers at the end of World War II. Its stated intentions are to: 'jerk the professional philosophers' from positions of 'entrenched independence' in order (in this era) to move intellectuals towards the 'de-Stalinisation' of philosophy. In 1976 another CIA report comments on the publication in Liberation, a newspaper with which Jean-Paul Sartre was associated, of a list of alleged CIA operatives working in France. A decade later, another document-France: Defection of Leftist Intellectuals-details matters closer to the home territory of contemporary philosophy of education. Its focus is on the changing intellectual climate amongst French thinkers, gauging the potential political and security impacts of change. Particularly lauded by the CIA are the 'New Philosophers' who have been 'assailing the French left as dangerous and implicitly totalitarian'. Due to the covert nature of such operations, the current intellectual engagements of security and intelligence agencies like the CIA are less easy to determine (Weinberg, 2017).

Nevertheless, the historical model of $\mathrm{CIA}$ engagement with for example French philosophy is illustrative of the potential power of such determinations, and the list of philosophers cited in such contexts regularly appear in the reference list of philosophers of education. Less so are the engagements of these thinkers within the CIA. The contributions of the structuralist historiography of Foucault to the anti-totalitarian, anti-Marxist New Right intellectual firmament make for potential re-readings for much of Foucault $(1970,1972,1977,2009,2010)$, if, that is, we were to side with conspiratorial stances (Rockhill, 2017). This article is not an encouragement to do so, but rather in consideration-as we have noted-of the power of the arts and the importance of aesthetic judgement in education to consider too the power behind the arts, their conceptualisations, constructions, production and, taking an adage from Watergate, to follow the money.

(3) The Educational Ecosystem of Literature as Securitisation

Three, our task then in philosophy of education might be defined by the need to draw out such systemic networks in order to clarify the political aspects of the aesthetic. Our case study of PEN is apposite here since it specifically unpicks the tortured bonds linking politics and literature. 
Philosophers of education, no less than any other socio-cultural critics, need here, then, not only to be informed by but to be informers of what Bronfenbrenner (1976) describes as an ecology of education systems, in other words, not simply examining institutional environments-policy, curriculum, aims and purposes-but setting these as part of wider ideological and political framings (Mueller and Toutain, 2015). Bronfenbrenner (1976) made ground-breaking inroads into the application of ecological models to education. His concerns were with rigour of scientific method. His notion of the 'experimental ecology of education' encouraging the study of education not simply in 'the laboratory' but in systems of lived educational experience, for example those formative influences on learning such as institutional, socio-economic, political, parental environments. Subsequent work by Bronfenbrenner $(1976,1994)$ placed the same scientific emphasis upon experimental method. Bronfenbrenner used the term ecology, then, to refer to systemic factors that impact on environments of and for learning. His methodological case being that failure to account for such environmental factors would mean educational research would be less not more scientifically rigorous than work undertaken under test or 'laboratory' conditions. Since Bronfenbrenner, others have adopted ecological models in a variety of disciplinary settings (Aldrich et al., 2008; Darling, 2007; Moen et al., 1995; Mueller and Toutain, 2015; Nambisan and Baron, 2013; Odum, 1997; Pickett and Cadenasso, 2002).

We may similarly think of our nexus of engagements as just another aspect of what intelligence theorists have called 'security communities' (Adler and Barnett, 1998). Our adaptation and refinement of an ecological metaphor suggests $\mathrm{CIA}$ engagement in literature and the arts is enacted as cultural engagement through a process of securitisation. Post-Snowden and post-Assange, continuing security and intelligence agency efforts to gather knowledge from a diversity of means and sources has helped define what some have termed a surveillance society (Greenwald, 2015; Harding, 2014; Leigh and Harding, 2011). The 'Copenhagen School' has done much to define 'securitisation' (Taureck, 2006; Williams, 2003; for critiques, see Buzan and Waever, 1997). Buzan (1991) People, States, and Fear was the basis for ground-breaking theorisations which identified five security sectors: military, political, societal, economic and environmental (Buzan et al., 1998; Buzan and Hansen 2009; also Huysmans, 1998; Adler and Barnett, 1998). Bagge Laustsen and Wæver (2000) later added religion as a sixth sector category. And as a major study of the political theology of the arts (Gearon, 2015), cultural and religious factors have come increasingly to the fore in considerations of the political aesthetic. CIA engagement in the arts and in PEN especially we determine as part of this process of securitisation, a process which seems beneath the radar of philosophy of education, but one which we consider, for the reasons outlined, worth bringing to light.

\section{CONCLUSION}

In sum, then, epistemologically, we suggest philosophers of education sharpen their treatments of literature in education with more realistic and informed assessments of the aesthetic in political and, here, security contexts. Methodologically, by implication, we also make the case for philosophers of education to make greater and more frequent use of primary documentary and archival sources in order to be able to substantiate such sharpened treatments.

The case we present here, then, is illustrative of a neglected cultural consideration for the arts in education and we wish to provoke debate. We have demonstrated through our case study on PEN 
and the $\mathrm{ClA}$ that there is a correlation between security and intelligence interests and the arts. Its interface with education though has been less thoroughly examined, though there are some interesting pockets of historical studies (Sinclair, 1989; Stonor Saunders, 2013; Winks, 1987).

Yet when a former director of the CIA (Dulles, 2006) writes a memoir/history of intelligence and uses the language of the aesthetic to title and frame the work-The Craft of Intelligence-we can assume the security and intelligence agencies have deep-set interests in aesthetics that philosophers of education might think worth noting.

\section{REFERENCES}

Adamson, W. L. (2003) Modernism in Art, Literature and Political Theory, in: T. Ball and R. Bellamy (eds), The Cambridge History of Twentieth Century Thought ( Cambridge: Cambridge University Press), pp. 412-430.

E. Adler and M. Barnett (eds) (1998) Security Communities ( Cambridge, Cambridge University Press).

Adorno, T. W., Benjamin, W., Bloch, E., Brecht, B. and Lukacs, G. (2007) Aesthetics and Politics ( London, Verso).

Aldrich, H., Hodgson, G., Hull, D., Knudsen, T., Mokyr, J. and Vanberg, V. (2008) In Defence of Generalized Darwinism, Journal of Evolutionary Economics, 18, pp. 577- 596.

Alexander, L. (2005) Is There a Right to Freedom of Expression? ( Cambridge, Cambridge University Press).

L. Appignanesi (ed.) (2006) Freedom of Expression is No Offence ( London, Penguin).

Arnold, M. (2009) Culture and Anarchy ( Oxford, Oxford University Press).

Bagge Laustsen, C. and Waever, O. (2000) In Defence of Religion: Sacred Referent Objects for Securitization. Millennium: Journal of International Studies, 29.3, pp. 705- 739.

Baudrillard, J. (2005) The System of Objects ( London, Verso). 
Benjamin, W. (2008) The Work of Art in the Age of Mechanical Reproduction ( London, Penguin).

Bigsby, C. (2011) Arthur Miller 1962-2005 ( Ann Arbor, MI, The University of Michigan Press).

Birkett, J. (2009) Margaret Storm Jameson: A Life ( Oxford, Oxford University Press).

Buzan, B. (1991) People, States, and Fear, 2nd ed. ( Boulder, CO, Lynne Rienner).

Buzan, B. and Hansen, L. (2009) The Evolution of International Security Studies ( Cambridge, Cambridge University Press).

Buzan, B. and Waever, O. (1997) Slippery? Contradictory? Sociologically Untenable? The Copenhagen School Replies. Review of International Studies, 23.2, pp. 241- 250.

Buzan, B., Waever, O. and de Wilde, J. (1998) Security: A New Framework for Analysis ( Boulder, CO, Lynne Rienner).

Bronfenbrenner, U. (1976) The Experimental Ecology of Education. Teachers College Record, 78.2, pp. 157- 204.

Bronfenbrenner, U. (1994) Ecological Models of Human Development, in: M. Gauvain and M. Cole (eds), International Encyclopedia of Education ( New York, W. H. Freeman), pp. 37-43.

Coleman, F. (1997) The Decline and Fall of the Soviet Empire: Forty Years That Shook the World, from Stalin to Yeltsin ( New York, St Martin's Press).

Darling, N. (2007) Ecological Systems Theory: The Person in the Center of the Circles. Research in Human Development, 4. 3-4, pp. 203-217. 
Debord, G. (1984) Society of the Spectacle ( New York, Black and Red).

Domhoff, G. W. (2017) Studying the Power Elite ( London, Routledge).

Dujmovic, N. (2007) Review of "Legacy of Ashes: The History of CIA" (London, Penguin). Available online at: https://www.cia.gov/library/center-for-the-study-of-intelligence/csi-publications/csistudies/studies/vol51no3/legacy-of-ashes-the-history-of-cia.html

Dulles, A. (2006) The Craft of Intelligence ( Guilford, CN, The Lyons Press).

Finn, P. and Couvee, P. (2015) The Zhivago Affair The Kremlin, the CIA, and the Battle over a Forbidden Book ( New York, Harvill Secker).

Foucault, M. (1970) The Order of Things ( London, Tavistock).

Foucault, M. (1972) The Archaeology of Knowledge ( New York, Pantheon).

Foucault, M. (1977) Discipline and Punish ( London, Allen Lane).

Foucault, M. (2009) Security, Territory, Population ( New York, Picador).

Foucault, M. (2010) The Birth of Biopolitics ( New York, Picador).

Garrard, J. and Garrard, C. (1990) Inside the Soviet Writers' Union ( New York, IB Tauris).

Gearon L. (2015) Religious Authority and the Arts: Conversations in Political Theology, Washington College Studies in Religion, Politics and Culture ( New York, Peter Lang).

Greenwald, G (2015) No Place to Hide, Edward Snowden, the NSA and the Surveillance State ( London, Picador).

Harding, L (2014) The Snowden Files, The Inside Story of the World's Most Wanted Man ( London, Guardian Faber Books).

Hobsbawm, E. (2007) The Age of Revolution: Europe 1789-1848 (London, Abacus).

Huysmans, J. (1998) Revisiting Copenhagen: Or, On the Creative Development of a Security Studies Agenda in Europe. European Journal of International Relations, 4.4, pp. 479- 505.

N. J. Karolides, M. Bald, D. B. Sova (eds) (2011) 120 Banned Books: Censorship Histories of World Literature ( New York, Checkmark).

Leigh, D and Harding, L (2011) Wikileaks, Inside Julian Assange's War on Secrecy ( London, Faber Guardian).

Jameson, F. (2002) The Political Unconscious: Narrative as a Socially Symbolic Act ( London and New York, Routledge).

Lyotard, J. F. (1984) The Postmodern Condition: A Report on Knowledge (Manchester, Manchester University Press). 
Stroud, Sutton Publishing).

Miller, A. (1987) Timebends ( New York, Grove Press).

Miller Harris, S. (2016) The CIA and the Congress for Cultural Freedom in the Early Cold War ( London, Routledge).

P. Moen, G. H. Elder and K. Luscher (eds) (1995) Examining Lives in Context: Perspectives on the Ecology of Human Development ( Washington, DC, American Psychological Association).

Mueller, S. and Toutain, O. (2015) The Outward Looking School and its Ecosystem ( Paris, OECD).

Nambisan, S. and Baron, R. A. (2013) Entrepreneurship in Innovation Ecosystems: Entrepreneurs' Self-Regulatory Processes and Their Implications for New Venture Success'. Entrepreneurship: Theory \& Practice, 37, pp. 1071- 1097.

Nussbaum, M. (2012) Not for Profit: Why Democracy Needs the Humanities ( Princeton, NJ, Princeton University Press).

Odum, E. P. (1997) Ecology: A Bridge Between Science and Society ( Sunderland, MA, Sinauer Associates).

Orwell, G. (1946) Why I Write ( London, Penguin).

Pickett, S. T. A. and Cadenasso, M. L. (2002) The Ecosystem as a Multidimensional Concept: Meaning, Model, and Metaphor. Ecosystems, 5, pp. 1- 10.

Reisch, A. (2013) Hot Books in the Cold War: The CIA-Funded Secret Western Book Distribution program Behind the Iron Curtain ( New York, Central European University Press).

Risso, L. (2014) Propaganda and Intelligence in the Cold War: The NATO Information Service ( London and New York, Routledge).

Rockhill, G. (2017) The CIA Reads French Theory: On the Intellectual Labour of Dismantling the Cultural Left. Available online at: http://thephilosophicalsalon.com/the-cia-reads-french-theory-onthe-intellectual-labor-of-dismantling-the-cultural-left/

Rousseau, J. J. (1997a) Rousseau: 'The Discourses' and Other Early Political Writings, V. Gourevitch (ed.) ( Cambridge, Cambridge University Press).

Rousseau, J. J. (1997b) Rousseau: 'The Social Contract' and Other Later Political Writings, V. Gourevitch (ed.) ( Cambridge, Cambridge University Press).

Sawyer, D. (2014) Lyotard, Literature and the Trauma of the Differend ( London, Palgrave).

Said, E. (1994) Culture and Imperialism ( London, Vintage).

Sinclair, A. (1989) The Red and the Blue: Intelligence, Treason and the Universities ( London, Coronet). 
York, The New Press).

Taureck, R. (2006) Securitisation Theory and Securitisation Studies. Journal of International Relations and Development, 9, pp. 53-61.

Trotsky, L. (1971) Literature and Revolution ( Cambridge, MA, University of Michigan Press).

Weinberg, J. (2017) The CIA's Reports on Philosophers, Daily Nous, 18 January. Available online at: http://dailynous.com/2017/01/18/cias-reports-philosophers/

Weiner, T. (2007) Legacy of Ashes: The History of the CIA ( London, Penguin).

Whitney, J. (2018) Finks: How the C.I.A. Tricked the World's Best Writers ( Berkeley, CA, OR Press). Wilkinson, N. (2009) Secrecy and the Media: The Official History of the United Kingdom's D-Notice System ( London, Routledge).

Williams, C. (2012) Researching Power, Elites and Leadership (London, SAGE).

Williams, E. (2016) The Ways We Think ( Oxford, Wiley-Blackwell).

Williams, M. C. (2003) Words, Images, Enemies: Securitization and International Politics.

International Studies Quarterly, 47.4, pp. 511- 531.

Winks, R. W. (1987) Cloak \& Gown, Scholars in the Secret War, 1939-1961 ( New York, William Morrow and Company, Inc.). 
